\title{
Evaluating the Triaxial Characteristics of Ultamafic Rocks from Central Greece Using the Physical, Dynamic and Mechanical Properties
}

\author{
Konstantinos Diamantis ${ }^{1 *}$, George Exarhakos ${ }^{2}$, George Migiros ${ }^{1}$, Efthimios Gartzos ${ }^{1}$ \\ ${ }^{1}$ Department of Sciences, Division of Geological Science and Atmospheric Environment, Laboratory of Mineralogy-Geology, Agricultural \\ University of Athens, Athens, Greece \\ ${ }^{2}$ Department of Civil Engineering, Piraeus University of Applied Sciences, Athens, Greece \\ Email: *kostasdiam@aua.gr
}

How to cite this paper: Diamantis, K., Exarhakos, G., Migiros, G. and Gartzos, E. (2016) Evaluating the Triaxial Characteristics of Ultamafic Rocks from Central Greece Using the Physical, Dynamic and Mechanical Properties. Open Access Library Journal, 3: e3214.

http://dx.doi.org/10.4236/oalib.1103214

Received: November 8, 2016

Accepted: November 21, 2016

Published: December 9, 2016

Copyright $\odot 2016$ by authors and Open Access Library Inc.

This work is licensed under the Creative Commons Attribution International License (CC BY 4.0).

http://creativecommons.org/licenses/by/4.0/

\section{(c) (i) Open Access}

\begin{abstract}
Due to the fact that the estimation of the triaxial parameters is very important in any geotechnical project, many attempts have become with the aim of their determination. In spite of its relative simplicity, triaxial tests are time consuming, expensive, and require a large number of well prepared (regularly shaped) rock specimens and suitable testing procedures. For this reason, they cannot be easily determined in rocks which are thinly bedded, highly fractured, weak, and so indirect, fast, practical, easy and economical ways should be used such as the correlation of them with some other characteristics which are calculated easily. The aim of this study is to apply correlation analysis to investigate the relationships between physical, dynamic and mechanical characteristics and triaxial parameters for ultramafic rocks. Thus, sixteen samples, taken from the western part of Othrysmt (ten samples) and the Kallidromomt (six samples, central Greece), were tested and the relations among the properties were described by simple regression analyses. The study reveals strong negative, logarithmic correlations between the effective porosity and triaxial parameters $(c, \varphi)$. Positive, linear relationships are also indicated between wave velocities, apparent cohesion and friction angle, while the increase of serpentinization percentage causes decrease of the $\mathcal{c}, \varphi$. Both dry unit weight and Schmidt Hammer Values are logarithmically affected with $c, \varphi$. The point load strength index and apparent cohesion and friction angle are strongly correlated by both logarithmic and linear functions, but logarithmic trends present higher determination coefficients.
\end{abstract}

\section{Subject Areas}

Civil Engineering 


\section{Keywords}

Triaxial Tests, Apparent Cohesion, Friction Angle, Ultramafic, Correlation, Greece

\section{Introduction}

The construction of geotechnical engineering projects like foundations, rock slopes and underground structures is based on the estimation of the rock mass properties. The determination of the triaxial parameters is very important because the rock-mass properties are estimated through them. Despite of its relative simplicity, triaxial tests are time consuming, expensive, and require a large number of well prepared (regularly shaped) rock specimens and suitabletesting procedures. Some rocks are thinly bedded, highly fractured, weak, present alterations such as ultramafic rocks with the result they are usually not suitable for preparing specimens and the determination of triaxial parameters is very difficult. On the other hand the fact that ultramafic rocks are met in many areas all over the world and especially south-eastern Europe has as a result many engineering geology projects to be constructed on/in them [1]. For the above-mentioned reasons, indirect, reliable, quick, sample and economical ways are necessary to estimate the triaxial parameters for the ultramafic rocks.

Ultramafic rocks are members of ophiolitic suite rocks which represent remnants of the Earth's oceanic crust and upper mantle. Basic, hypabyssal and extrusive rocks cover ultramafic rocks. This succession is idealized and in most cases some members may be absent. This research focuses on ultramafic rocks. They include particular types of geological formation with both petrographic variety (harzburgites, lherzolites, plagioclastic peridotites, dunites, etc.) and structural complexity due to tectonic deformation and alteration. This ocean-floor metamorphism (serpentinization) lead to a modification of their petrographic characteristics (serpentinized varieties of them). Thus, they are from massive strong to weak rocks (peridotites and serpentinites, [1]-[8]).

Within the framework of the present study, sixteen ultramafic rocks (six peridotites and ten serpentinites) were taken from the Kallidromomt and the western part of Othrysmt (Central Greece), the dry unit weight $\left(\gamma_{d}\right)$, the effective porosity $\left(n_{e}\right)$, the compressional wave velocity $\left(V_{p}\right)$, the shear wave velocity $\left(V_{s}\right)$, the Schmidt Hammer Values (SHV), the point load strength index $\left(I_{550}\right)$ were determined and presented. The Uniaxial Compressive Strength $\left(\sigma_{c i}\right)$ and the material constant $\left(m_{i}\right)$ were estimated by the Hoek and Brown failure criterion and the triaxial characteristics (apparent cohesion, $\mathrm{c}$ and friction angle $\varphi$ ) were presented.

The main objective of this research is was to determine the predictability of apparent cohesion (c) and friction angle $(\varphi)$ of ultramafic rocks (serpentinites and peridotites) with a simple, fast, practical and economical way through the physical, dynamic and mechanical properties at the preliminary site investigation stage. The results were statistically analyzed using the method of least-squares regression. The relationships among these parameters were described by the best fit equations and the highest correlation 
coefficient, in each relationship, was also determined. The same samples were subjected to petrographic studies with the aim of describing the main mineralogical composition and the serpentinization percentage of ultramafic rocks.

\section{Location and Geology of the Study Area}

The study area is to be found in the central part of Greece (Figure 1(a)) and specifically

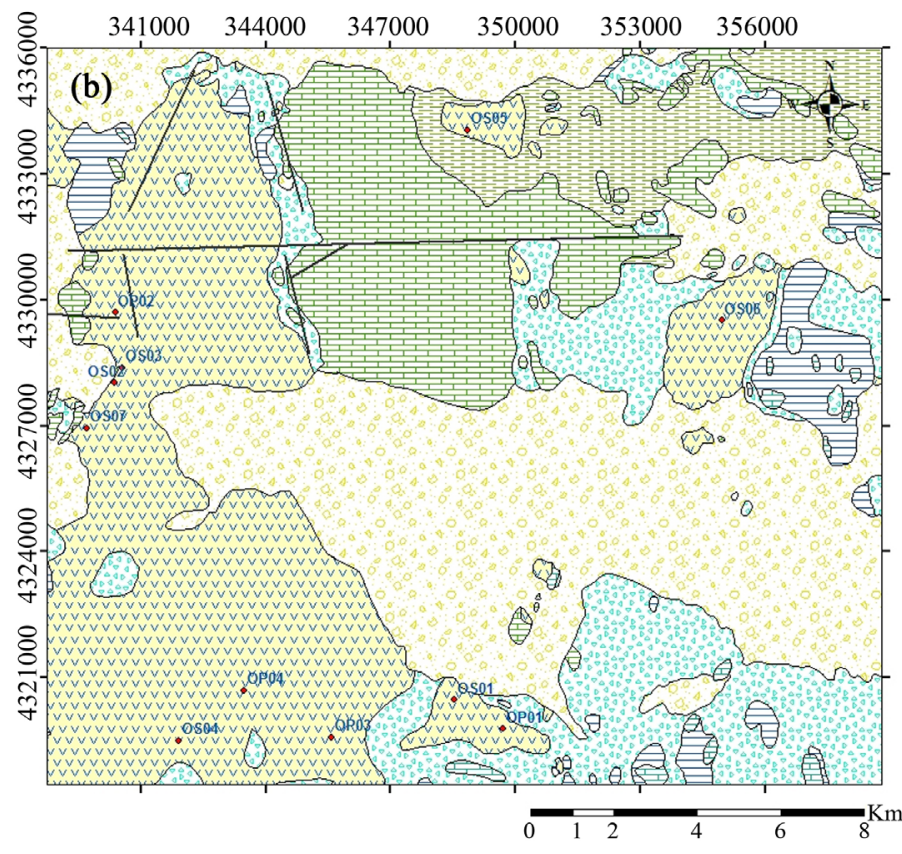

LEGEND

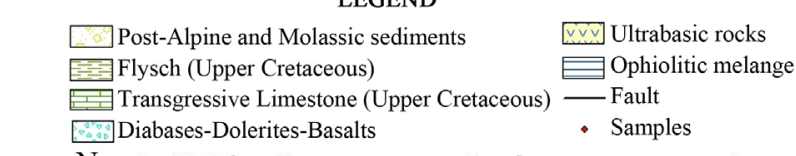

(a)

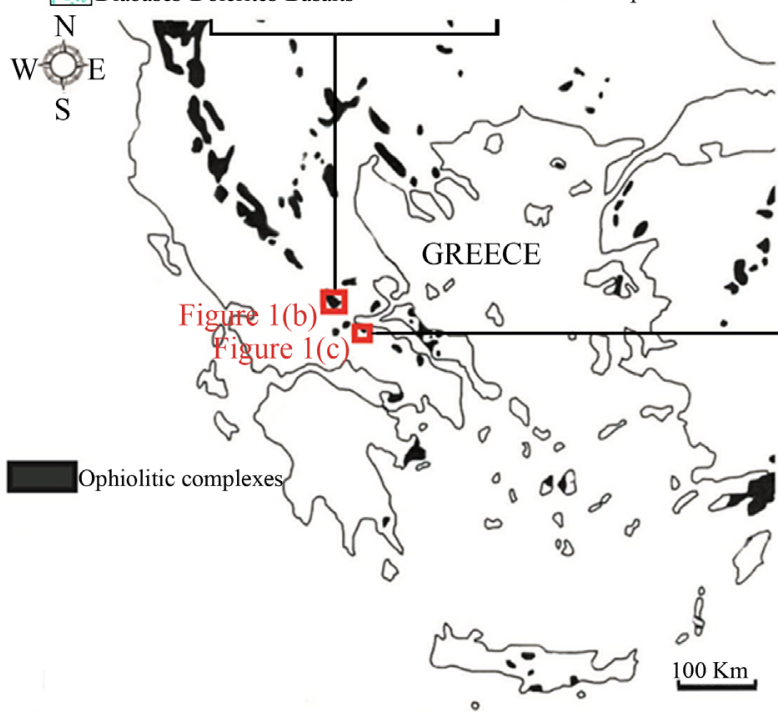

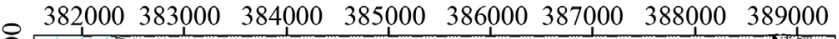

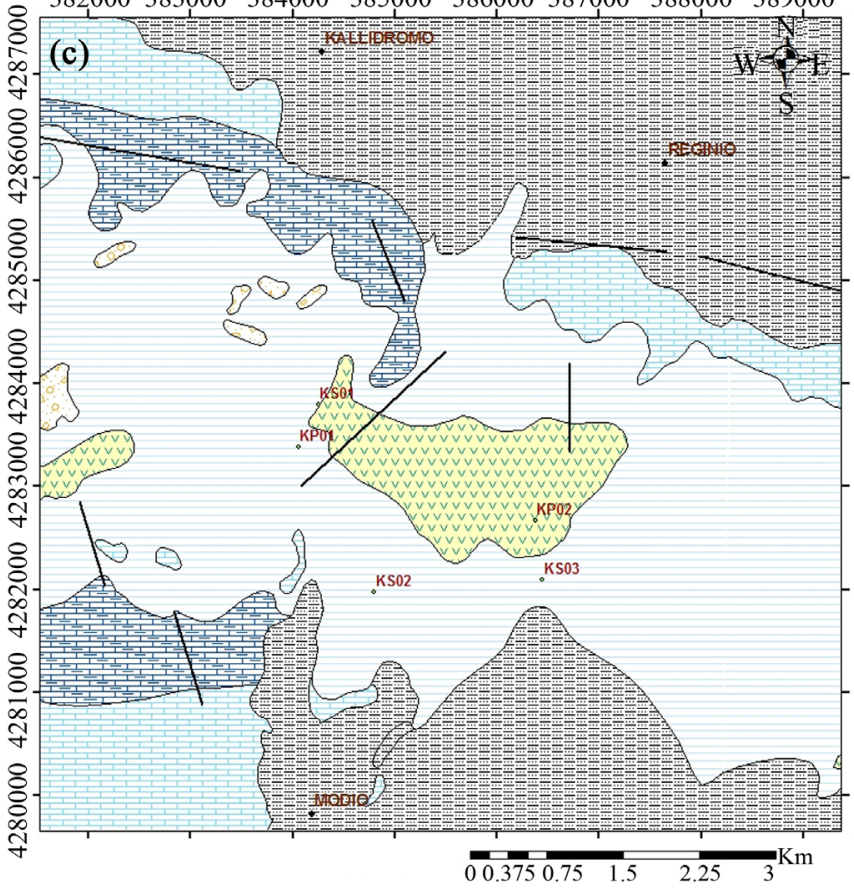

LEGEND

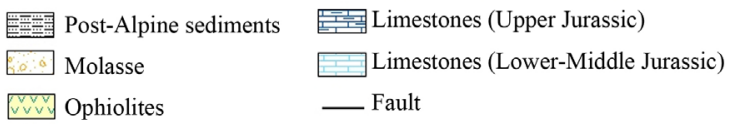

Figure 1. (a) Study areas and ophiolitic complexes in Greece; (b) Geologigal map and sampling points of the study area at Othrys Mt; (c) Geologigal map and sampling points of the study area at Kallidromo Mt. 
at western part of Othrys Mt. (near the villages of Moschokarya, Mega Isoma, LoutraKaitsas and Domokos, Figure 1(b)) and at the eastern-southeastern side of Kallidromo Mt (between the villages of Kallidromo, Reginio and Modio, Figure 1(c)). It belongs to the Sub-Pelagonian geotectonical unit, which is part of the Internal Hellenides and is mainly comprised of Alpine formations ([9] [10] [11] [12]). They can be distinguished into:

1) A carbonate sequence of Triassic-Jurassic age which constitutes the basement of the area.

2) A tectonic nappe, mainly ophiolitic (volcano-sedimentary formations, basaltic lavas, basic rocks and ultramafic masses, [11]).

3) An unconformable sequence of Cretaceous limestones which passes upward to flysch.

The present study research focuses on ophiolitic sequence and mainly on ultramafic masses. They are mainly represented by the peridotites whose degree of serpentinization varies.

\section{Methods and Results}

\subsection{Sample Preparation and Test Procedures}

The data pertains to ultramafic rocks sampled from sixteen sites in the study areas (eleven from Othrys and six from Kallidromo, Figure 1). The samples were taken from the surface and cylindrical rock specimens for laboratory testing were prepared according [13] requirements. To reduce the uncertainty regarding the influence of the sample size on the measured properties and especially on strength [14] [15], their diameters range between 53 and $55 \mathrm{~mm}$, the length to diameter ratio was between 2.0 and 2.5 and the edges of the specimens were cut parallel and smooth [13]. After a macroscopical inspection, seventy-four isotropic, homogeneous, unweathered (or slightly weathered) and free of visible joints ultramafic specimens were considered. The dry unit weight and the effective porosity were determined in accordance with [16]. The sound velocities $\left(V_{p}, V_{s}\right)$ were calculated from the travel time with the application of ultrasonic compression wave pulses to the samples in accordance with test designations [17]. Moreover, point load strength index values were determined according to [18] requirements (in sixteen specimens, ten serpentinites and six peridotites) and a Type $\mathrm{L}$ Schmidt Hammer was used for the determination of Schmidt Hammer Values. Ten points on each specimen were taken and the mean values were calculated. The Schmidt hammer tests were carried out according to [16]. In addition, the triaxial tests were determined using a Hoek cell according to [19]. Three or four different confining pressures $\left(\sigma_{3}\right)$ applied during the triaxial tests (fifty-eight specimens). Range of confining pressures of $0<\sigma_{3}<0.5 \sigma_{c i}$, proposed by [14], was used. The specimens were first subjected to the required confining pressure and then the axial load was applied until the specimen failed.

Thin sections, from samples of the sixteen areas, were prepared and examined under the polarizing microscope, at the Mineralogy-Geology Laboratory of the Agricultural 
University of Athens, with the aim of describing the main mineralogical composition and the serpentinization percentage of ultramafic rocks. Fractures created by the tests, did not follow internal discontinuities and were always fresh. The tests were carried out in dry conditions for a better relation of the results.

\subsection{Petrographic Properties of Ultramafic Rocks}

The ultramafic rocks include rock types (peridotites) with large variability (harzburgites, lherzolites, plagioclasticperidotites, dunites, etc.), which due to their tectonic deformation and a low grade metamorphism (serpentinization, [20]) lead to a modification of their petrographic characteristics (serpentinites). Serpentinisation is the transformation of ferromagnesian minerals, olivine in particular, to serpentine, which is a lattice mineral of either fibrous or laminar form. This alteration allows the understanding of the dramatic changes in the behavior of ultramafic rocks, reduces their strength and generally the physical, dynamic and mechanical characteristics [1]-[8].

In this paper, sixteen thin sections were prepared and examined under a polarizing microscope. The studied rock samples are unaltered or slightly serpentinized (serpentinization $<30 \%$ by volume) ultramafic rock types, characterized as peridotites and partially to completely serpentinizedperidotites (serpentinization $>70 \%$ by volume) called as serpentinites. The investigated peridotites mainly comprised of olivines, ortho and clino pyroxenes which are characterised as parent-primary minerals $\left(P_{m}>74 \%\right.$ by volume, Table 1).

When the peridotites are influenced by the serpentinization, they transformed into Serpentinites. Serpentinites are mainly composed of secondary minerals (70\% - 92\%, by volume, Table 1$)$. Serpentine is the major mineral phase $(62 \%-84 \%$ by volume, Table1, [1]). Also, some other secondary minerals are chlorite, talc and actinolite comprising up to $13 \%$. Thus, the percentage of the remaining parent rock minerals (olivine, pyroxene), is less than $30 \%$. The mean values of serpentinization for peridotites and serpentinites are $9.17 \%$ and $79.90 \%$ respectively, while the standard deviations are 8.75 and 7.02 respectively (Table 2 ).

\subsection{Physical, Dynamic and Mechanical Properties}

The dry unit weight $\left(\gamma_{d}\right)$ and effective porosity $\left(n_{e}\right)$ were determinedfor 6 peridotites and 10 serpentinites samples and their values are listed in Table 3 . The $\gamma_{d}$ and $n_{e}$ for peridotites range from 31.67 to $33.17 \mathrm{KN} / \mathrm{m}^{3}$ and from 0.07 to 0.19 respectively. On the other hand, the values of $\gamma_{d}$ and $n_{e}$ for serpentinites fluctuate between 24.95 and $26.79 \mathrm{KN} / \mathrm{m}^{3}$ and from 0.39 to 3.59 respectively. The serpentinites present lower dry unit weight values and higher effective porosity than peridotites because they are mainly composed of secondary minerals (as it is afore-mentioned) which have lower specific gravity and more voids.

The compressional wave velocity $\left(V_{p}\right)$ and shear wave velocity $\left(V_{s}\right)$, which were determined as above-mentioned in chapter 3.1, are given in Table 3 as well. The values of $V_{p}$ for peridotites and serpentinites fluctuate between 7412 and $7991 \mathrm{~m} / \mathrm{sec}$ and from 4955 to $5645 \mathrm{~m} / \mathrm{sec}$ respectively, while the mean values are $7781 \mathrm{~m} / \mathrm{sec}$ (S.D. 211) and 5361 
Table 1. Primary minerals, secondary minerals and serpentinization percentage for ultramafic rocks.

\begin{tabular}{|c|c|c|c|c|c|c|c|c|c|c|}
\hline \multirow{2}{*}{$\begin{array}{c}\text { Sample } \\
\text { No }\end{array}$} & \multicolumn{5}{|c|}{ Primary Minerals } & \multicolumn{4}{|c|}{ Secondary Minerals } & \multirow{2}{*}{$\begin{array}{c}\text { Degree of } \\
\text { Serpentinization } \\
b(\%)\end{array}$} \\
\hline & $\begin{array}{c}\mathrm{O} \\
(\%)\end{array}$ & $\begin{array}{l}\text { Opx } \\
(\%)\end{array}$ & Cpx (\%) & $\mathrm{Pl}(\%)$ & $\mathrm{Sp}(\%)$ & Serp (\%) & $\mathrm{Chl}(\%)$ & $\mathrm{Tc}(\%)$ & Act (\%) & \\
\hline КР01 & 71 & 22 & & & & 6 & 1 & & & 7 \\
\hline KP02 & 75 & 21 & - & - & 1 & 3 & - & - & - & 3 \\
\hline OP01 & 50 & 11 & 12 & - & 1 & 22 & 2 & 1 & 1 & 26 \\
\hline 0P02 & 66 & 21 & - & - & 2 & 10 & 1 & - & - & 11 \\
\hline OP03 & 74 & 19 & 3 & - & - & 3 & 1 & - & - & 4 \\
\hline OP04 & 85 & 10 & - & - & 1 & 2 & 2 & - & - & 4 \\
\hline KS01 & 9 & 9 & 5 & - & 1 & 63 & 4 & 5 & 4 & 76 \\
\hline KS02 & 10 & 6 & 3 & - & 1 & 71 & 2 & 7 & - & 80 \\
\hline KS03 & 10 & 7 & 11 & - & 2 & 62 & 7 & 1 & - & 70 \\
\hline OS01 & 5 & 3 & - & - & - & 84 & 5 & 2 & 1 & 92 \\
\hline OS02 & 8 & 6 & - & - & - & 76 & 6 & 3 & 1 & 86 \\
\hline OS03 & 7 & 6 & - & - & - & 79 & 7 & 1 & - & 87 \\
\hline OS04 & 8 & 11 & 7 & - & 1 & 66 & 4 & 2 & 1 & 73 \\
\hline OS05 & 6 & 9 & - & - & 2 & 79 & 2 & 1 & 1 & 83 \\
\hline OS06 & 13 & 8 & - & - & 1 & 68 & 5 & 4 & 1 & 78 \\
\hline OS07 & 14 & 11 & - & - & 1 & 69 & 4 & 1 & - & 74 \\
\hline
\end{tabular}

KP: Peridotite of Kallidromo, OP: Peridotite of Othrys, KS: Serpentinite of Kallidromo, OS: Serpentinite of Othrys.

Table 2. Statistical analysis of the serpentinization percentage for ultramafic rocks.

\begin{tabular}{ccc}
\hline & Peridotites & Serpentinites \\
\cline { 2 - 3 } & $\begin{array}{c}\text { Serpentinization } \\
\text { percentage, } \beta(\%)\end{array}$ & $\begin{array}{c}\text { Serpentinization } \\
\text { percentage, } \beta(\%)\end{array}$ \\
\hline Maximum value & 26 & 92 \\
Minimum value & 3 & 70 \\
Mean value & 9.17 & 79.90 \\
Standard Deviation & 8.75 & 7.02 \\
\hline
\end{tabular}

$\mathrm{m} / \mathrm{sec}$ (S.D. 225) respectively. As far as $V_{s}$ values are concerned, they vary between 4171 and $4539 \mathrm{~m} / \mathrm{sec}$ for peridotites and from 2464 to $3044 \mathrm{~m} / \mathrm{sec}$ for serpentinites. The mean values for serpentinites and peridotites are 2795 and $4392 \mathrm{~m} / \mathrm{sec}$ respectively. According to [2] [3] and [5], both unit weight and velocities decrease with increasing of serpentinization.

Moreover, the Schmidt Hammer Values (SHV) range between 61.25 and 64.69 for peridotites (Table 3), present mean value 63.75 and their standard deviation is 1.24 . On 
Table 3. Physical, dynamic and mechanical property values for ultramafic rocks.

\begin{tabular}{ccccccc}
\hline $\begin{array}{c}\text { Samples } \\
\text { No }\end{array}$ & $\begin{array}{c}\text { Effective } \\
\text { Porosity, } n_{e}\end{array}$ & $\begin{array}{c}\text { Dry Unit } \\
\text { Weight, } \gamma_{d} \\
\left(\mathrm{KN} / \mathrm{m}^{3}\right)\end{array}$ & $\begin{array}{c}\text { Comp. Wave } \\
\text { Velocity, } V_{p} \\
(\mathrm{~m} / \mathrm{sec})\end{array}$ & $\begin{array}{c}\text { Shear } \\
\text { Wave } \\
\text { Velocity, } V_{s} \\
(\mathrm{~m} / \mathrm{sec})\end{array}$ & $\begin{array}{c}\text { Schmidt } \\
\text { Hammer } \\
\text { Values, } \\
\text { SHV }\end{array}$ & $\begin{array}{c}\text { The point } \\
\text { load } \\
\text { strength } \\
\text { index, } I_{50} \\
(\mathrm{MPa})\end{array}$ \\
\hline KP01 & 0.07 & 33.1 & 7959 & 4539 & 64.08 & 10.63 \\
KP02 & 0.11 & 32.92 & 7850 & 4458 & 64.69 & 10.14 \\
OP01 & 0.19 & 31.67 & 7412 & 4171 & 61.25 & 8.27 \\
OP02 & 0.14 & 32.13 & 7704 & 4290 & 64.13 & 7.27 \\
OP03 & 0.09 & 33.02 & 7769 & 4372 & 64.17 & 10.53 \\
OP04 & 0.08 & 33.17 & 7991 & 4524 & 64.15 & 10.42 \\
KS01 & 0.64 & 26.2 & 5442 & 2850 & 52.97 & 3.94 \\
KS02 & 0.75 & 26.12 & 5473 & 2888 & 52.73 & 3.41 \\
KS03 & 0.39 & 26.79 & 5646 & 3044 & 54.49 & 4.91 \\
OS01 & 3.59 & 24.95 & 4955 & 2464 & 49.52 & 2.01 \\
OS02 & 2.36 & 25.08 & 5152 & 2666 & 50.55 & 2.28 \\
OS03 & 2.29 & 25.37 & 5154 & 2640 & 50.7 & 3.19 \\
OS04 & 0.51 & 26.6 & 5637 & 3000 & 54.02 & 4.42 \\
OS05 & 1.6 & 25.61 & 5313 & 2727 & 51.5 & 3.23 \\
OS06 & 1.26 & 25.93 & 5320 & 2748 & 51.89 & 2.81 \\
OS07 & 0.53 & 26.35 & 5520 & 2928 & 53.34 & 3.85 \\
\hline
\end{tabular}

the other hand, in serpentinites the SHV vary from 49.52 to 54.49 , the mean value is 52.17 and their standard deviation is 1.61 (Table 4).

In this research, only diametrical point load tests were carried out on the samples. The point load strength index $\left(I_{550}\right)$ (referred to a standard size $50 \mathrm{~mm}$ ) values are listed in Table 3. The point load strength index values range from 2.01 to $4.91 \mathrm{MPa}$ in serpentinites and between 7.27 and $10.63 \mathrm{MPa}$ in peridotites. The mean values are 3.41 (S.D. 0.91) and 9.54 MPa (S.D. 1.42) respectively (Table 4).

In this research, the triaxial tests were carried out in fifty-eight specimens (three confining pressures at least in each sample ranging from 3 to $18 \mathrm{MPa}$, Table 5) and the material constant $\left(m_{i}\right)$ and the $\sigma_{c i}$ were estimated by the Hoek and Brown failure criterion (Table 5). For this criterion [14] [21] [22] [23] [24], the maximum and minimum total stresses at failure $\left(\sigma_{1}\right.$ and $\left.\sigma_{3}\right)$ for intact rock are correlated by the following equation:

$$
\sigma_{1}=\sigma_{3}+\sigma_{c i}\left[m_{i} \frac{\sigma_{3}}{\sigma_{c i}}+1\right]^{1 / 2}
$$

where,

$\sigma_{1}, \sigma_{3}$, the maximum and minimum (confining) total stresses at failure for intact rock, 
Table 4. Statistical analysis of the physical, dynamic and mechanical properties for ultramafic rocks.

\begin{tabular}{|c|c|c|c|c|c|}
\hline & & $\begin{array}{l}\text { Maximum } \\
\text { value }\end{array}$ & $\begin{array}{l}\text { Minimum } \\
\text { value }\end{array}$ & Mean value & $\begin{array}{l}\text { Standard } \\
\text { Deviation }\end{array}$ \\
\hline \multirow{6}{*}{ Peridotites } & Effective Porosity, $n_{e}$ & 0.19 & 0.07 & 0.12 & 0.04 \\
\hline & $\begin{array}{l}\text { Dry Unit Weight, } \gamma_{d} \\
\left(\mathrm{KN} / \mathrm{m}^{3}\right)\end{array}$ & 33.17 & 31.67 & 32.67 & 0.62 \\
\hline & $\begin{array}{c}\text { Comp. Wave } \\
\text { Velocity, } V_{p}(\mathrm{~m} / \mathrm{sec})\end{array}$ & 7991 & 7412 & 7781 & 211 \\
\hline & $\begin{array}{c}\text { Shear Wave } \\
\text { Velocity, } V_{s}(\mathrm{~m} / \mathrm{sec})\end{array}$ & 4539 & 4171 & 4392 & 143 \\
\hline & $\begin{array}{l}\text { Schmidt Hammer } \\
\text { Values, SHV }\end{array}$ & 64.69 & 61.25 & 63.75 & 1.24 \\
\hline & $\begin{array}{l}\text { The point load } \\
\text { strength index, } I_{550} \\
(\mathrm{MPa})\end{array}$ & 10.63 & 7.27 & 9.54 & 1.42 \\
\hline \multirow{6}{*}{ Serpentinites } & Effective Porosity, $n_{e}$ & 3.59 & 0.39 & 1.39 & 1.06 \\
\hline & $\begin{array}{l}\text { Dry Unit Weight, } \gamma_{d} \\
\left(\mathrm{KN} / \mathrm{m}^{3}\right)\end{array}$ & 26.79 & 24.95 & 25.90 & 0.63 \\
\hline & $\begin{array}{c}\text { Comp. Wave } \\
\text { Velocity, } V_{p}(\mathrm{~m} / \mathrm{sec})\end{array}$ & 5645 & 4955 & 5361 & 225 \\
\hline & $\begin{array}{c}\text { Shear Wave } \\
\text { Velocity, } V_{s}(\mathrm{~m} / \mathrm{sec})\end{array}$ & 3044 & 2464 & 2795 & 180 \\
\hline & $\begin{array}{l}\text { Schmidt Hammer } \\
\text { Values, SHV }\end{array}$ & 54.49 & 49.52 & 52.17 & 1.61 \\
\hline & $\begin{array}{c}\text { The point load } \\
\text { strength index, } I_{550} \\
(\mathrm{MPa})\end{array}$ & 4.91 & 2.01 & 3.41 & 0.91 \\
\hline
\end{tabular}

$\sigma_{c i}$, the uniaxial compressive strength of intact rock,

$m_{i}$, the material constant which depends on the properties of intact rock.

Finally the apparent cohesion $(c)$ and the friction angle $(\varphi)$ for intact rock were calculated using triaxial compressive strength test data (Table 5). The confining pressures were plotted against axial stresses with the $\sigma_{3}$ as abscissa and the $\sigma_{1}$ as ordinates (Figure 2 and Figure 3). The best linear lines passing through the points are fitted using the least squares technique. The regression functions of this line for peridotites and serpentinites are respectively:

$$
\sigma_{1}=9.16 \sigma_{3}+188.72
$$

and

$$
\sigma_{1}=5.85 \sigma_{3}+73.07
$$

Furthermore, $c$ and $\varphi$ were calculated using the following equations: 
Table 5. The maximum and minimum (confining) total stresses, the material constant, the friction angle, the apparent cohesion and the estimated uniaxial compressive Strength values for ultramafic rocks.

\begin{tabular}{|c|c|c|c|c|c|c|c|}
\hline $\begin{array}{c}\text { Sample } \\
\text { No }\end{array}$ & $\begin{array}{c}\text { Axial } \\
\text { Load, } \\
P \\
(\mathrm{kN})\end{array}$ & $\begin{array}{c}\text { Axial } \\
\text { Stress, } \\
\sigma_{1}= \\
\mathrm{P} / \mathrm{A} \\
(\mathrm{MPa})\end{array}$ & $\begin{array}{l}\text { Confining } \\
\text { Pressure, } \\
\sigma_{3}(\mathrm{MPa})\end{array}$ & $\begin{array}{c}\text { Material } \\
\text { constant, } \\
m_{i}\end{array}$ & $\begin{array}{l}\text { Friction } \\
\text { Angle, } \varphi \\
\left(^{\circ}\right)\end{array}$ & $\begin{array}{c}\text { Apparent } \\
\text { Cohesion, } \\
c(\mathrm{MPa})\end{array}$ & $\begin{array}{l}\text { Estimated } \\
\text { Uniax. } \\
\text { Compressive } \\
\text { Strength, } \\
\sigma_{\text {ciestm }}(\mathrm{Mpa})\end{array}$ \\
\hline KP01A & 520 & 224.66 & 3 & \multirow{4}{*}{26.58} & \multirow{4}{*}{54.13} & \multirow{4}{*}{32.18} & \multirow{4}{*}{184.43} \\
\hline КР01B & 605 & 261.39 & 6 & & & & \\
\hline KP01C & 857 & 370.26 & 18 & & & & \\
\hline KP01D & 651 & 281.26 & 9 & & & & \\
\hline KP02A & 573 & 247.56 & 3 & \multirow{4}{*}{28.16} & \multirow{4}{*}{54.78} & \multirow{4}{*}{35.54} & \multirow{4}{*}{206.44} \\
\hline КР02B & 609 & 263.12 & 6 & & & & \\
\hline KP02C & 906 & 391.43 & 18 & & & & \\
\hline KP02D & 809 & 349.53 & 9 & & & & \\
\hline KS01A & 220 & 95.05 & 3 & \multirow{3}{*}{14.27} & \multirow{3}{*}{44.10} & \multirow{3}{*}{16.98} & \multirow{3}{*}{73.97} \\
\hline KS01B & 269 & 116.22 & 6 & & & & \\
\hline KS01C & 338 & 146.03 & 12 & & & & \\
\hline KS02A & 232 & 102.11 & 3 & \multirow{3}{*}{14.39} & \multirow{3}{*}{44.64} & \multirow{3}{*}{17.94} & \multirow{3}{*}{79.95} \\
\hline KS02B & 276 & 121.47 & 6 & & & & \\
\hline $\mathrm{KS02C}$ & 350 & 154.04 & 12 & & & & \\
\hline KS03A & 337 & 148.87 & 3 & \multirow{4}{*}{16.04} & \multirow{4}{*}{46.58} & \multirow{4}{*}{24.48} & \multirow{4}{*}{115.37} \\
\hline KS03B & 344 & 151.96 & 6 & & & & \\
\hline KS03C & 539 & 238.11 & 18 & & & & \\
\hline KS03D & 406 & 179.35 & 9 & & & & \\
\hline OP01A & 284 & 122.70 & 3 & \multirow{4}{*}{21.09} & \multirow{4}{*}{48.17} & \multirow{4}{*}{20.96} & \multirow{4}{*}{95.89} \\
\hline OP01B & 369 & 159.43 & 6 & & & & \\
\hline OP01C & 534 & 230.71 & 18 & & & & \\
\hline OP01D & 398 & 171.95 & 9 & & & & \\
\hline OP02A & 486 & 214.69 & 3 & \multirow{4}{*}{25.20} & \multirow{4}{*}{53.37} & \multirow{4}{*}{30.33} & \multirow{4}{*}{170.27} \\
\hline OP02B & 531 & 233.70 & 6 & & & & \\
\hline OP02C & 789 & 348.54 & 18 & & & & \\
\hline OP02D & 596 & 263.29 & 9 & & & & \\
\hline OP03A & 582 & 250.53 & 3 & \multirow{4}{*}{27.76} & & & \\
\hline OР03B & 609 & 262.15 & 6 & & 5501 & 3385 & 20041 \\
\hline OP03C & 918 & 395.16 & 18 & & 35.01 & נינ. & \\
\hline OP03D & 726 & 312.51 & 9 & & & & \\
\hline OP04A & 520 & 229.71 & 3 & 26.69 & 54.09 & 32.84 & 187.52 \\
\hline
\end{tabular}




\section{Continued}

\begin{tabular}{|c|c|c|c|c|c|c|c|}
\hline OP04B & 567 & 250.48 & 6 & & & & \\
\hline OP04C & 837 & 369.75 & 18 & & & & \\
\hline OP04D & 685 & 302.60 & 9 & & & & \\
\hline OS01A & 116 & 50.12 & 3 & \multirow{3}{*}{12.76} & \multirow{3}{*}{38.05} & \multirow{3}{*}{9.88} & \multirow{3}{*}{33.55} \\
\hline OS01B & 163 & 70.42 & 6 & & & & \\
\hline OS01C & 208 & 89.54 & 12 & & & & \\
\hline OS02A & 133 & 57.25 & 3 & \multirow{3}{*}{13.10} & \multirow{3}{*}{39.59} & \multirow{3}{*}{10.44} & \multirow{3}{*}{37.96} \\
\hline OS02B & 168 & 72.32 & 6 & & & & \\
\hline OS02C & 228 & 98.14 & 12 & & & & \\
\hline OS03A & 161 & 69.30 & 3 & \multirow{4}{*}{13.52} & \multirow{4}{*}{39.44} & \multirow{4}{*}{12.54} & \multirow{4}{*}{45.00} \\
\hline OS03B & 174 & 74.90 & 6 & & & & \\
\hline OS03C & 311 & 133.87 & 18 & & & & \\
\hline OS03D & 222 & 95.56 & 9 & & & & \\
\hline OS04A & 238 & 102.45 & 3 & \multirow{3}{*}{14.82} & \multirow{3}{*}{44.92} & \multirow{3}{*}{18.15} & \multirow{3}{*}{81.01} \\
\hline OS04B & 291 & 125.73 & 6 & & & & \\
\hline OS04C & 362 & 155.83 & 12 & & & & \\
\hline OS05A & 174 & 74.90 & 3 & \multirow{3}{*}{13.67} & \multirow{3}{*}{42.00} & \multirow{3}{*}{13.81} & \multirow{3}{*}{55.47} \\
\hline OS05B & 222 & 95.56 & 6 & & & & \\
\hline OS05C & 282 & 121.39 & 12 & & & & \\
\hline OS06A & 221 & 97.27 & 3 & \multirow{4}{*}{13.86} & \multirow{4}{*}{42.17} & \multirow{4}{*}{18.24} & \multirow{4}{*}{73.9} \\
\hline OS06B & 246 & 108.27 & 6 & & & & \\
\hline OS06C & 391 & 172.08 & 18 & & & & \\
\hline OS06D & 305 & 134.23 & 9 & & & & \\
\hline OS07A & 268 & 117.95 & 3 & \multirow{4}{*}{15.52} & \multirow{4}{*}{44.64} & \multirow{4}{*}{21.21} & \multirow{4}{*}{92.32} \\
\hline OS07B & 297 & 131.20 & 6 & & & & \\
\hline Os07C & 460 & 202.45 & 18 & & & & \\
\hline OS07D & 365 & 160.05 & 9 & & & & \\
\hline
\end{tabular}

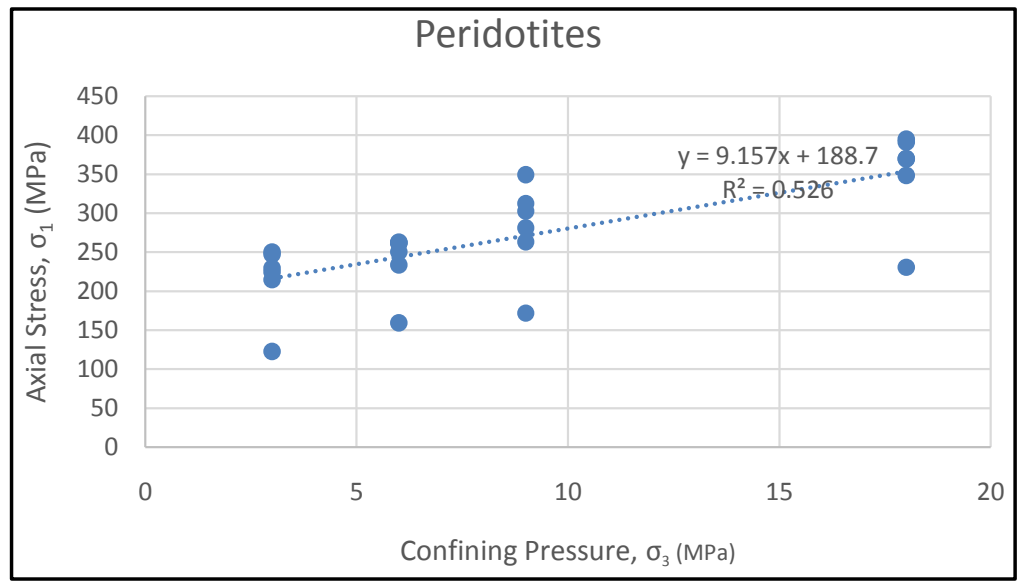

Figure 2. The confining pressures $\left(\sigma_{3}\right)$ against axial stresses $\left(\sigma_{1}\right)$ for Peridotites. 


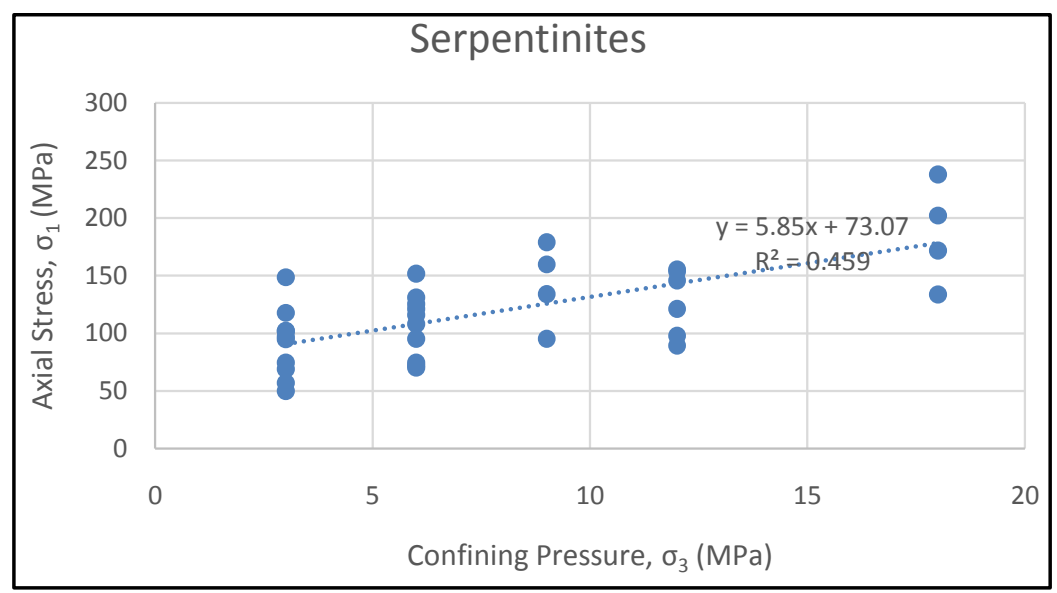

Figure 3. The confining pressures $\left(\sigma_{3}\right)$ against axial stresses $\left(\sigma_{1}\right)$ for Serpentinites.

$$
\begin{aligned}
& \varphi=\arcsin ((\alpha-1) /(\alpha+1)) \\
& c=\sigma_{c i}(1-\sin \varphi) 2 \cos \varphi
\end{aligned}
$$

where

a, the gradient of the Equations (2) and (3).

\section{Correlation Analysis}

Least squares regression analysis was applied in order to describe the relationships among triaxial characteristics $(c, \varphi)$, physical, dynamic, mechanical properties and the petrographic data of the ultramafic rocks. The equation of the best-fit line and the determination coefficient $\left(R^{2}\right)$ were determined for each regression. Techniques from Excel 2003 software (Analysis ToolPak program) was used to process the data.

\section{Correlation between Triaxial Parameters and Physical, Dynamic and Mechanical Properties}

In this study, an attempt to correlate $c$ and $\varphi$ with dry unit weight is respectively presented in Figure 4 and Figure 5. The logarithmic equation seems to fit better $\left(R^{2}=\right.$ $0.84)$ the dry unit weight with the apparent cohesion while the relationship between $\varphi$ and $\gamma_{d}$ is better described by the linear equation $\left(R^{2}=0.92\right)$. The regression lines representing the best fit between effective porosity and $c, \varphi$ are logarithmic (Figure 6 and Figure 7). The apparent cohesion and the friction angle using the effective porosity values can be expressed by the empirical equations:

$$
\begin{gathered}
c=-6.34 \ln \left(n_{e}\right)+16.83\left(R^{2}=0.91\right) \\
\varphi=-4.46 \ln \left(n_{e}\right)+43.08\left(R^{2}=0.96\right)
\end{gathered}
$$

Moreover, the plots of the apparent cohesion values as a function of sound velocities $\left(V_{p}, V_{s}\right)$ values are shown in Figure 8. The best fit relationships are found to be linear and the determination coefficients are 0.83 and 0.84 respectively. The correlations between the friction angle and the wave velocities were also determined. A positive 


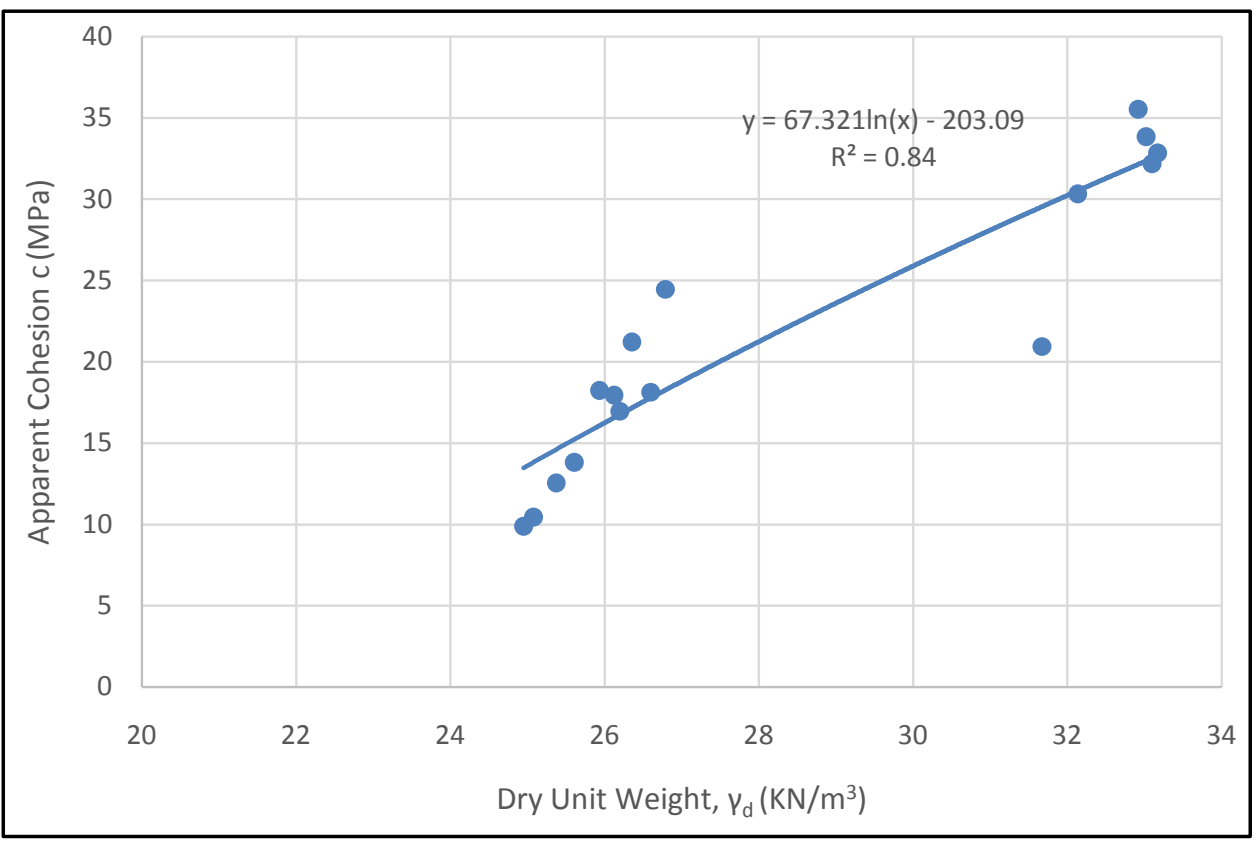

Figure 4. Relationship between apparent cohesion and dry unit weight for ultramafic rocks.

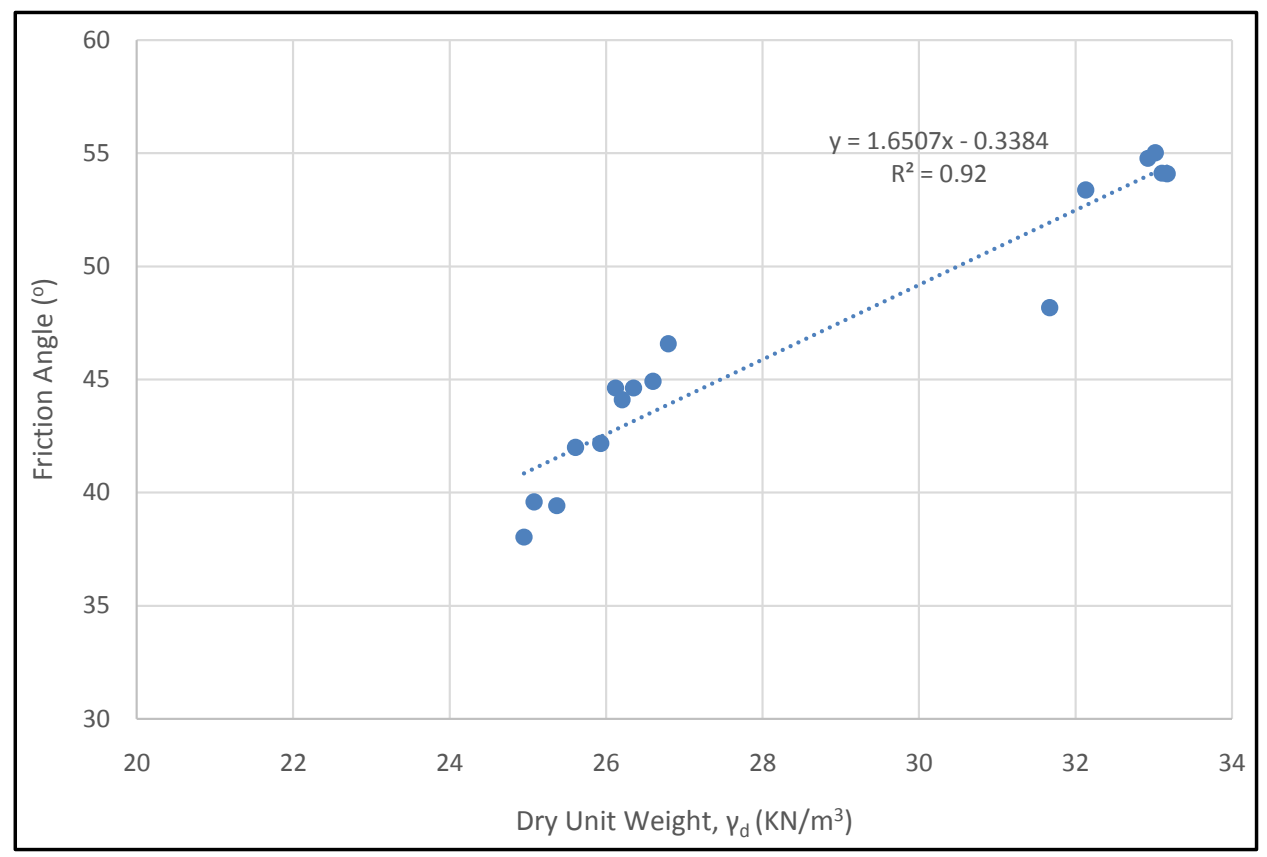

Figure 5. Correlation between friction angle and dry unit weight for ultramafic rocks.

relationship was found between the $\varphi$ and the $V_{p}, V_{s}$ (Figure 9) indicating that the friction angle increase with increasing wave velocities. The logarithmic model gives high $R^{2}$ values, but better correlation is described by the linear trends (Figure 9).

As it is illustrated in Figure 10, Figure 11 the friction angle and apparent cohesion present visible correlations with the degree of serpentinization $(\beta)$. The $c, \varphi$ decrease linearly with the increase of $\beta$. The relationship between $\varphi$ and $\beta$ presents higher 


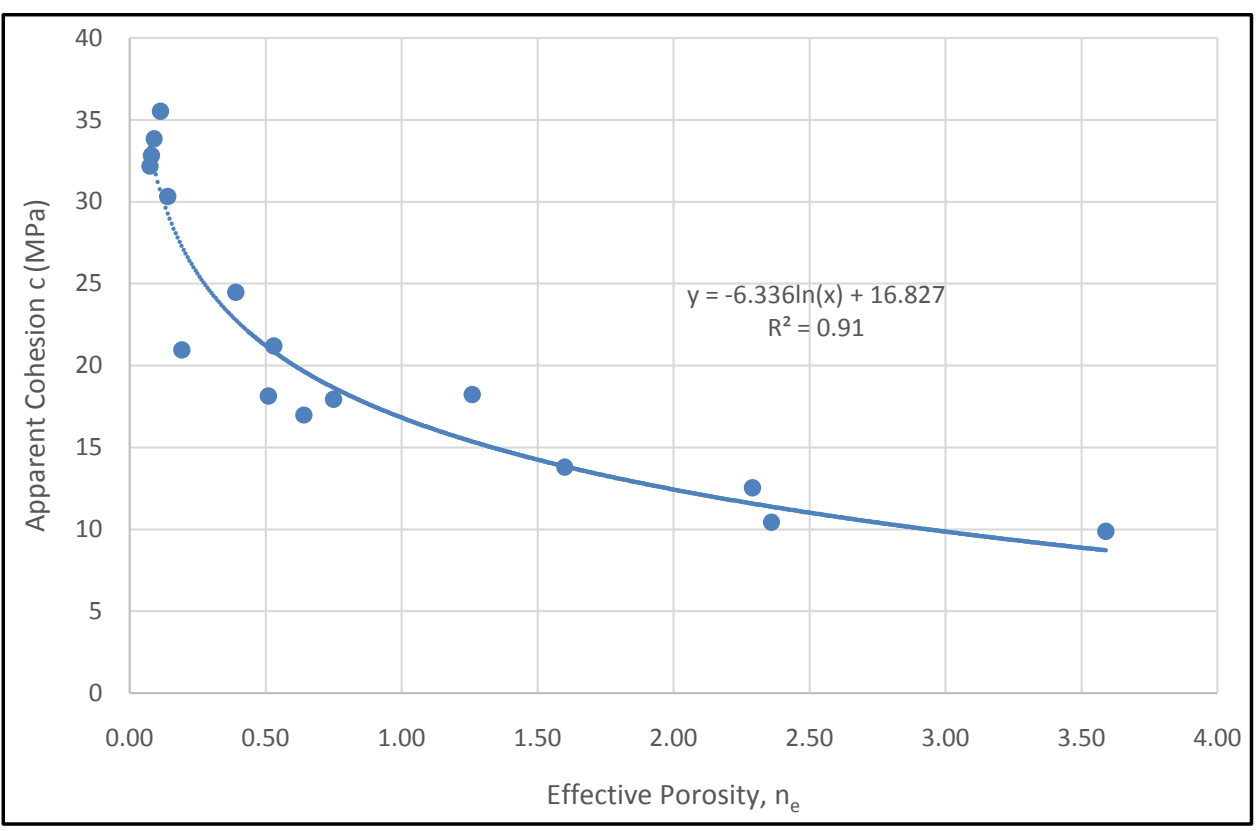

Figure 6. Relation between apparent cohesion and effective porosity for ultramafic rocks.

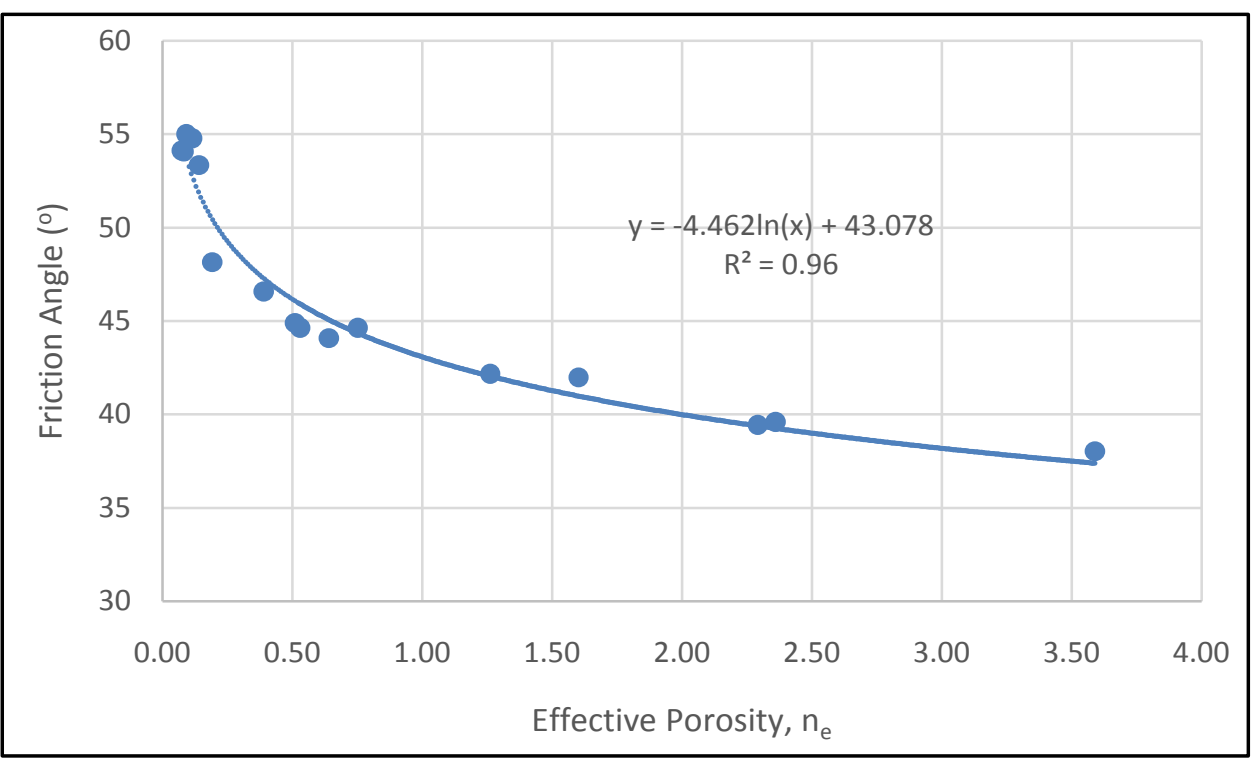

Figure 7. Logarithmic function between friction angle and effective porosity for ultramafic rocks.

determination coefficient $\left(R^{2}=0.93\right)$ than that between $c$ and $\beta\left(R^{2}=0.86\right)$.

In addition, Figure 12 presents the plot of the apparent cohesion against Schmidt Hammer Values $(S H V)$. The best fit equation is logarithmic and the relation between them presents high determination coefficient $\left(R^{2}=0.88\right)$. The plots of the friction angle as a function of the SHV are shown in Figure 13. The best fit equation is logarithmic with high determination coefficient $\left(R^{2}=0.95\right)$.

As shown in Table 6, linear and logarithmic functions can describe the relationships between $c$ and $I_{550}$ and between $\varphi$ and $I_{550}$. The logarithmic equations seem to fit better 


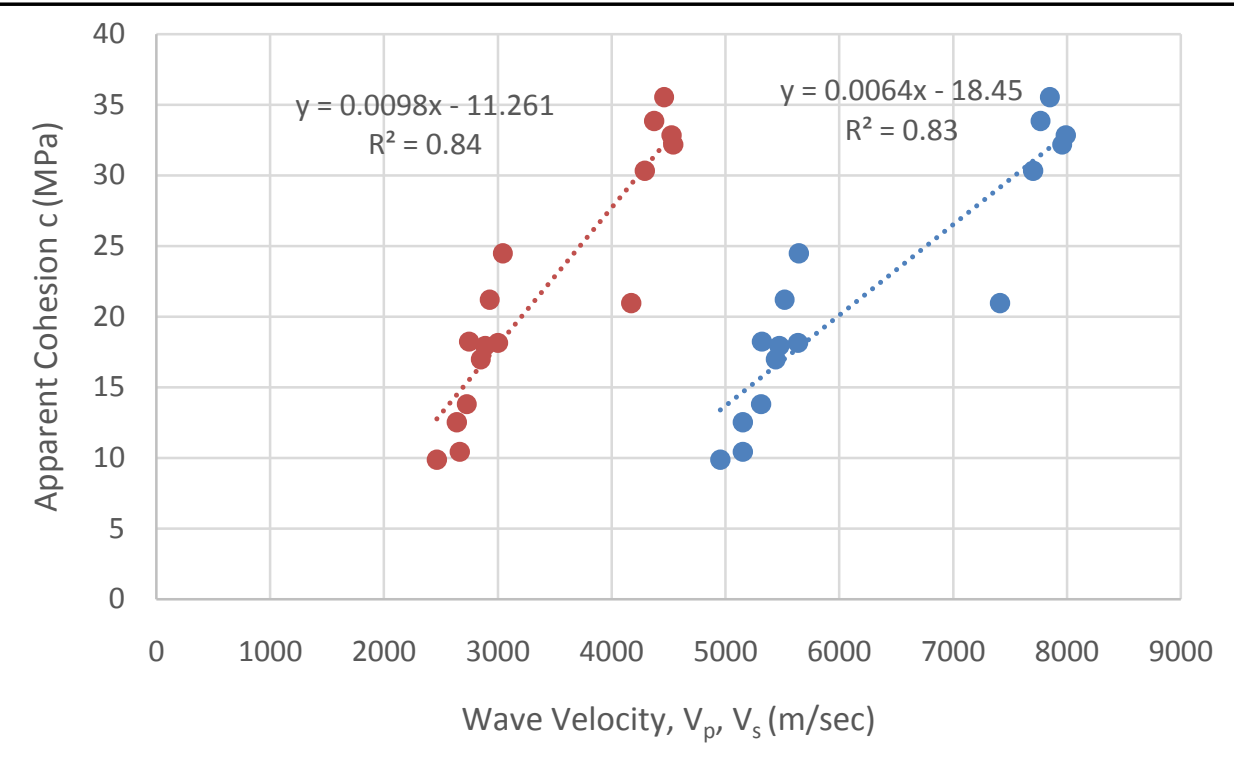

Figure 8. Relationship of wave velocities with apparent cohesion for ultramafic rocks.

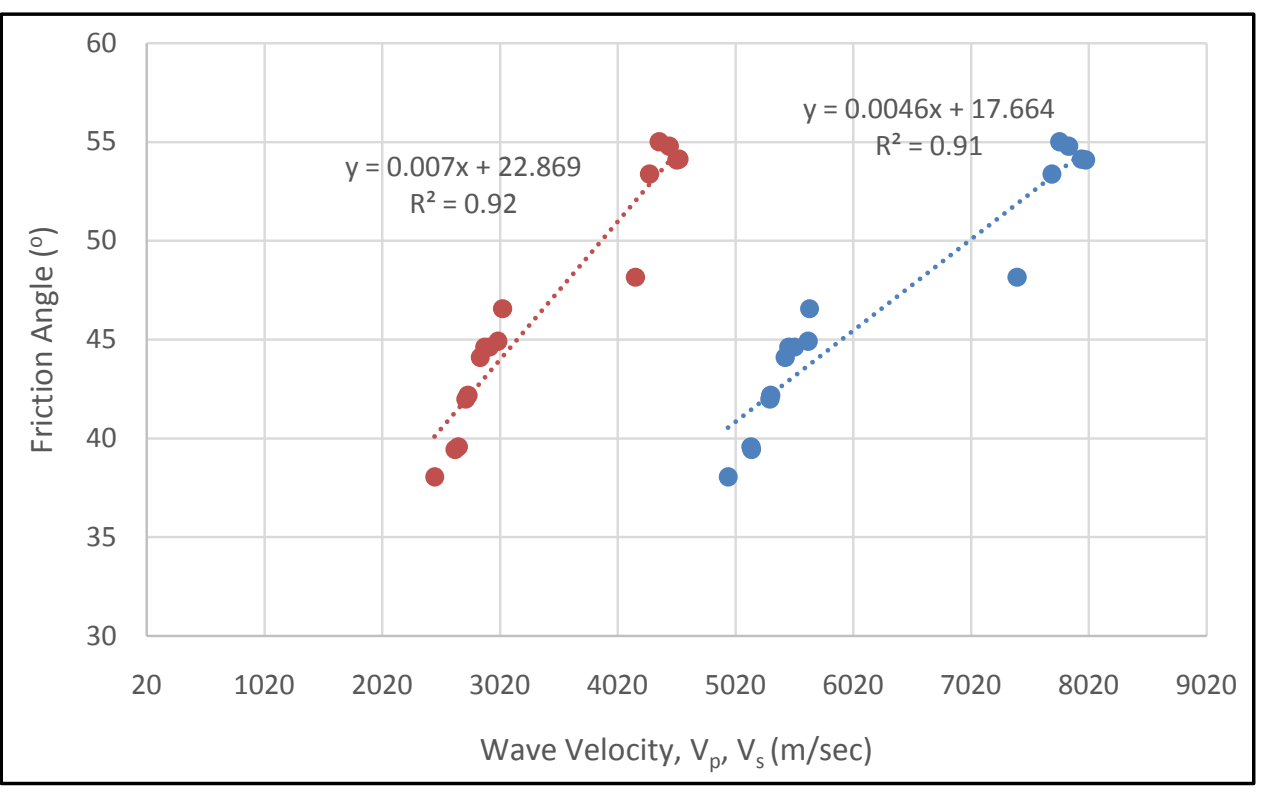

Figure 9. Correlation between wave velocities and friction angle for ultramafic rocks.

the above-mentioned properties than the linear equations, exhibiting $R$-square values 0.87 and 0.93 respectively. The logarithmic functions are illustrated in Figure 14 and Figure 15.

\section{Conclusions}

The estimation of the triaxial parameters is considered to be the most important component in any engineering geology project because the rock-mass properties are calculated through them. Despite of their simple, fast and easy determination, they require a 


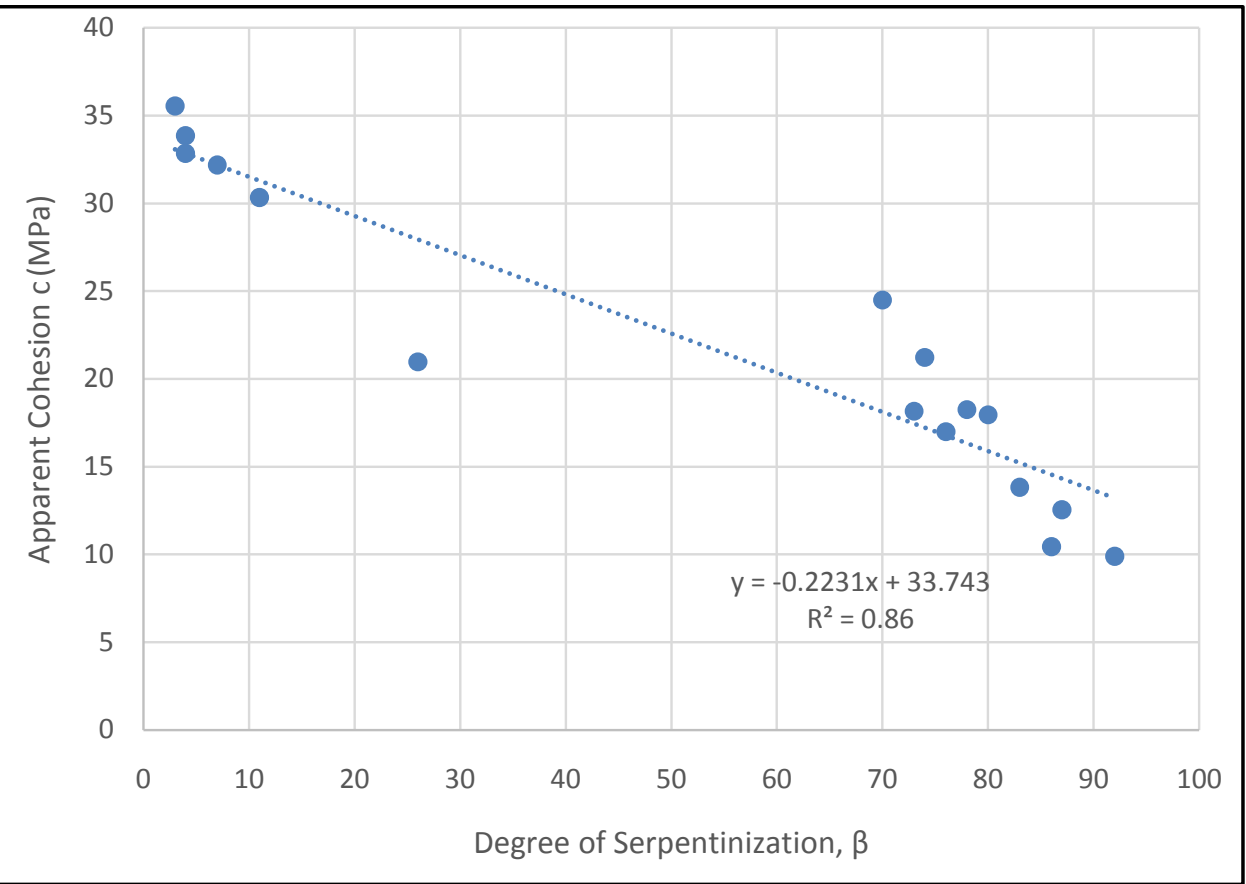

Figure 10. Relationship between degree of serpentinization and apparent cohesion for ultramafic rocks.

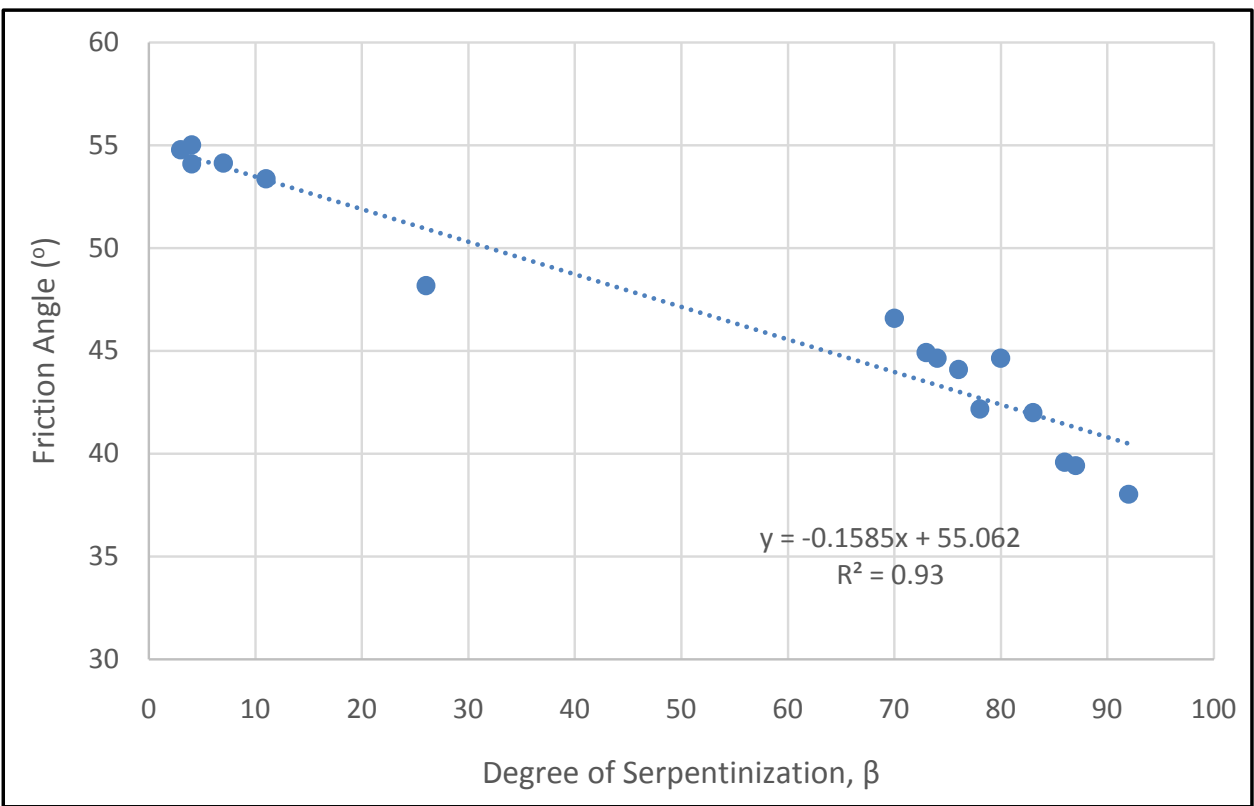

Figure 11. Correlation between degree of serpentinization and friction angle for ultramafic rocks.

large number of well prepared (regularly shaped) rock specimens. But ultramafic rocks (especially serpentinites) are usually not suitable for preparing specimens. Thus, the immediate determination of the triaxial characteristics is usually difficult for these rocks. For this reason, this study mainly attempts to develop empirical equations between triaxial parameters and physico-mechanical properties. 


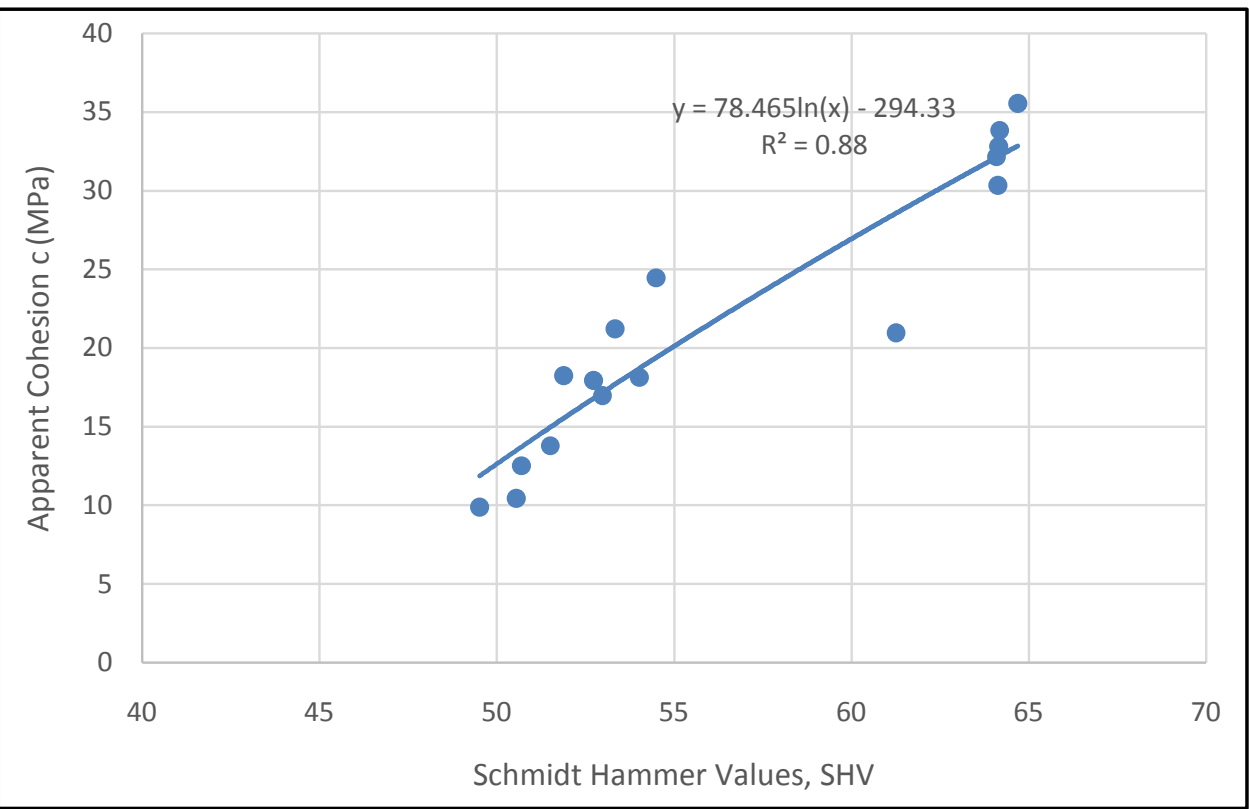

Figure 12. Relationship of Schmidt hammer values with apparent cohesion for ultramafic rocks.

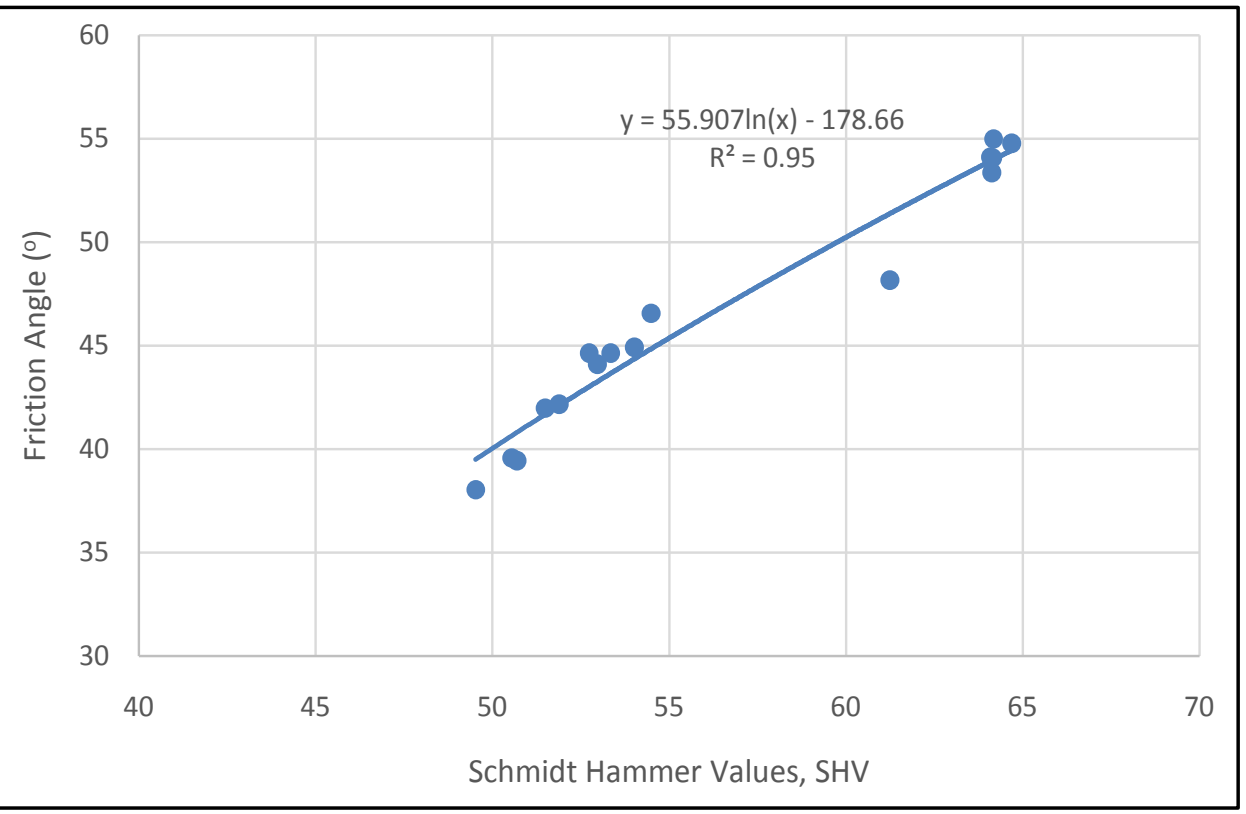

Figure 13. Variation of Schmidt hammer values against friction angle for ultramafic rocks.

In this paper ultramafic samples, taken from sixteen sites of central Greece (western part of Othrysmt and the Kallidromomt), were tested in laboratory and the triaxial properties were predicted through the wave velocities by simple regression analysis.

The research demonstrates that the friction angle $(\varphi)$ exhibits strong linear correlation with the dry unit weight $\left(\gamma_{d}\right)\left(R^{2}=0.92\right)$ while the logarithmic equation seems to correlate better $\left(R^{2}=0.84\right)$ the dry unit weight with the apparent cohesion $(c)$.

Significant negative logarithmic relationships exist between the triaxial parameters 


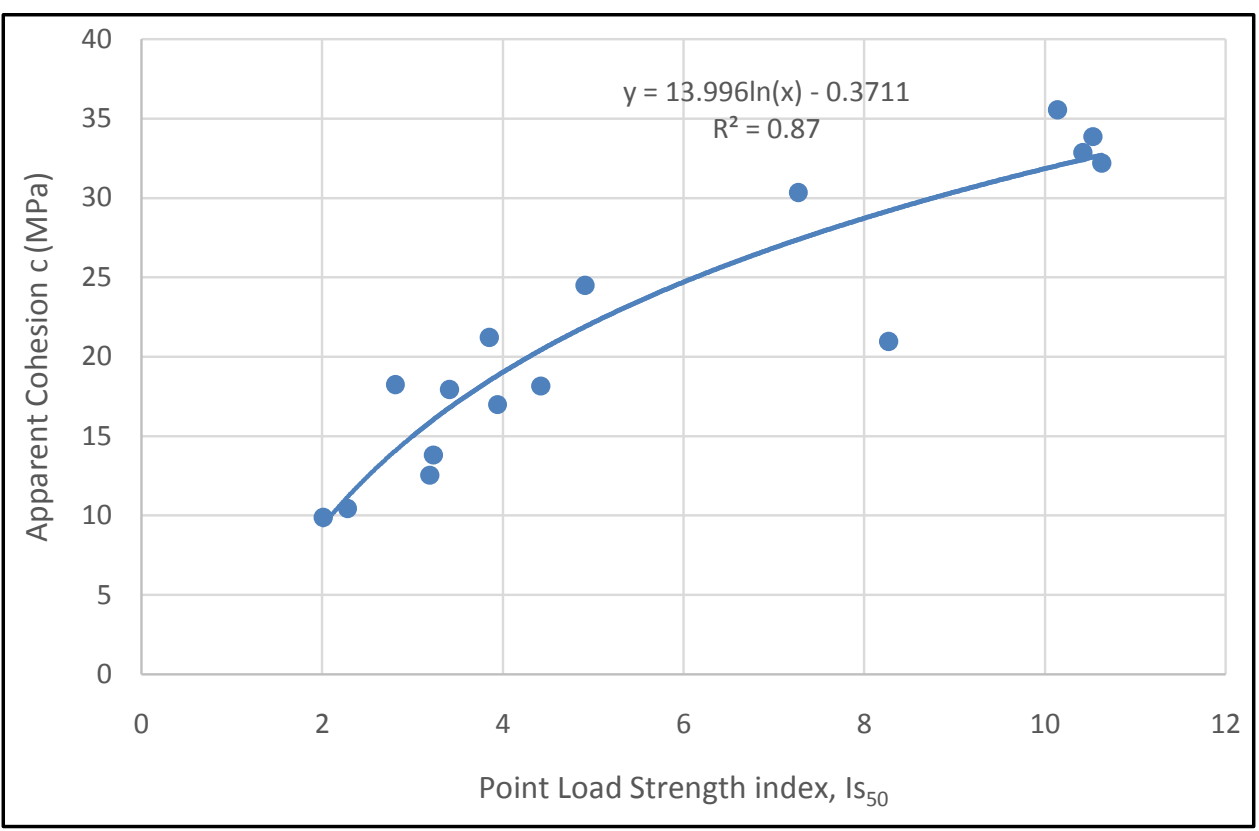

Figure 14. Correlation between point load strength index and friction angle for ultramafic rocks.

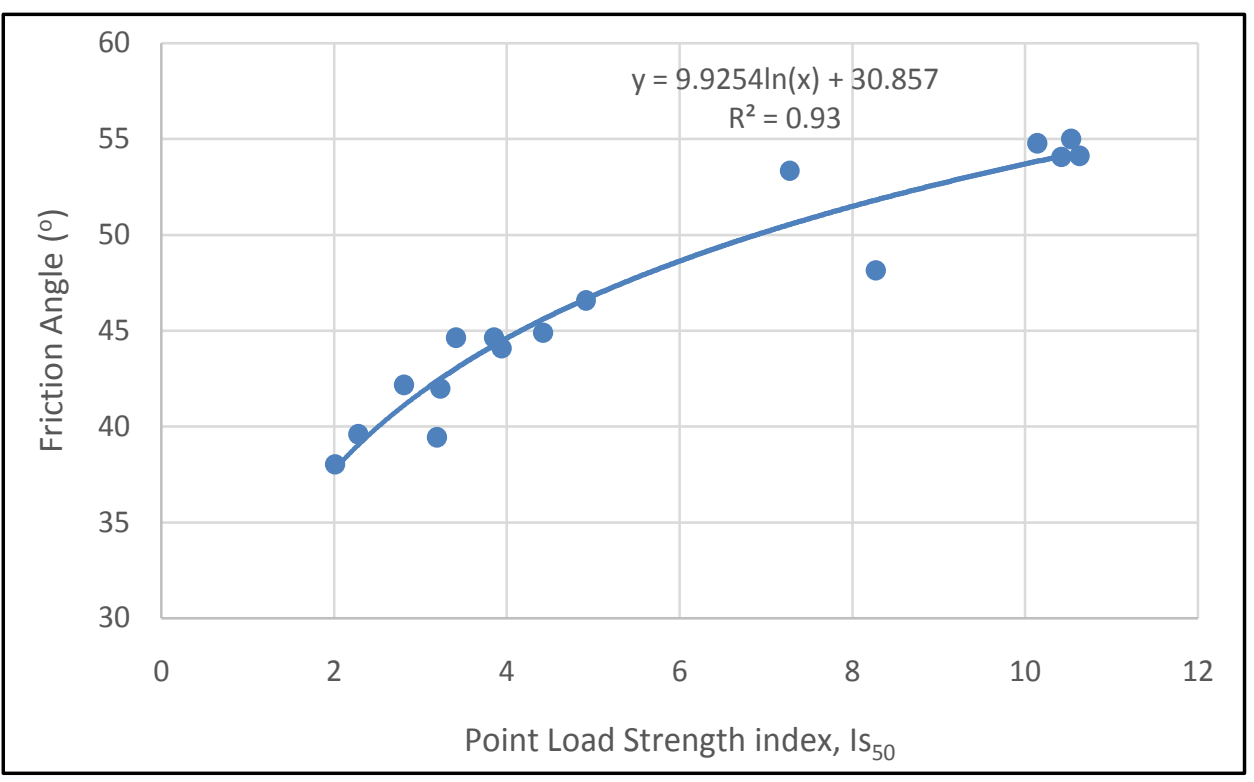

Figure 15. Relationship between point load strength index and apparent cohesion for ultramafic rocks.

and the effective porosity $\left(n_{e}\right)$. The relation between $\varphi$ and $n_{e}$ presents higher determination coefficient $\left(R^{2}=0.96\right)$ than that between $c$ and $n_{e}\left(R^{2}=0.91\right)$.

The wave velocities are positively correlated with $c$ and $\varphi$ and provide high determination coefficient. In particular, $\varphi$ presents higher correlation with $V_{p}, V_{s}\left(R^{2}=0.91, R^{2}=\right.$ 0.92 respectively) than $c\left(R^{2}=0.83, R^{2}=0.84\right.$ respectively).

The effect of alteration on the physico-mechanical properties of ultramafic rocks can be characterized quantitatively by the serpentinization percentage $(\beta)$. Strong inverse linear 
Table 6. Regression equations and determination coefficients $\left(R^{2}\right)$ for ultramafic rocks.

\begin{tabular}{ccc}
\hline Parameters to be related & Regression Equations & $R^{2}$ \\
\hline Apparent cohesion and point load strength index & $c=13.996 \ln \left(I_{\mathrm{s} 50}\right)-0.3711$ & 0.87 \\
Apparent cohesion and point load strength index & $c=2.4611 I_{s 50}+7.7905$ & 0.85 \\
Friction angle and point load strength index & $\varphi=9.9254 \ln \left(I_{\mathrm{s} 50}\right)+30.857$ & 0.93 \\
Friction angle and point load strength index & $\varphi=1.7408 I_{s 50}+36.67$ & 0.91 \\
\hline
\end{tabular}

relationships exist between the $\beta$ and $c, \varphi$. The relationship between $\varphi$ and $\beta$ presents higher determination coefficient $\left(R^{2}=0.93\right)$ than that between $c$ and $\beta\left(R^{2}=0.86\right)$.

The relations between $c, \varphi$ and Schmidt hammer values (SHV) are also expressed by logarithmic functions. The SHV shows higher correlation $\left(R^{2}=0.95\right)$ with the friction angle than that with apparent cohesion $\left(R^{2}=0.88\right)$.

Both the $c$ and $\varphi$ exhibit negative relationships with the point load strength index $\left(I_{50}\right)$. The best fit trends are logarithmic and $\varphi$ presents higher correlation with $I_{550}\left(R^{2}=\right.$ $0.93)$ than that c with $I_{550}\left(R^{2}=0.87\right)$.

Some observed deviations may be due to the petrographic variety, the different serpentinization degree, the structural complexity and the internally imprinted tectonic deformation of studied rocks.

All empirical methods evaluated in this study can be used for an assessment of the triaxial characteristics of ultramafic rocks, especially for serpentinites whose preparation in standard size cores, is quite difficult. However, it is commonly known that the prediction equations derived by different researches are dependent on rock types, quality, test conditions and different tectonic settings.

\section{Acknowledgements}

This study was funded by the State Scholarship Foundation of Greece (I.K.Y). The authors would also like to express their thanks to the Public Works Central Laboratory of Greece (KEDE) and to Ass. Professor Anastasios Tsagalidis for his help in petrography.

\section{References}

[1] Diamantis, K. (2010) Engineering Geological Properties of the Ultrabasic Rocks in Othrys and Kallidromo Mountains (Central Greece). PhD Thesis, Agricultural University of Athens, Athens, 386.

[2] Christensen, N.I. (1966) Shear-Wave Vetocities in Metamorphic Rocks at Pressures to 10 Kbar. Journal of Geophysical Research, 71, 3549-3556. https://doi.org/10.1029/JZ071i014p03549

[3] Christensen, N.I. (2004) Serpentinites, Peridotites and Seismology. International Geology Review, 46, 795-816. https://doi.org/10.2747/0020-6814.46.9.795

[4] Ramana, Y.V., Gogte, B.S. and Sarma, K. (1986) Physical Properties of Indus Ophiolites from Kashmir Himalaya. Physics of the Earth and Planetary Interiors, 43, 104-122. https://doi.org/10.1016/0031-9201(86)90079-8 
[5] Escartin, J., Hirth, G. and Evans, B. (2001) Strength of Slightly Serpentinized Peridotites: Implications for the Tectonics of Oceanic Lithosphere. Geological Society of America, 29, 1023-1026. https://doi.org/10.1130/0091-7613(2001)029<1023:sosspi>2.0.co;2

[6] Marinos, P., Hoek, E. and Marinos, V. (2006) Variability of the Engineering Properties of Rock Masses Quantified by the Geological Strength Index: The Case of Ophiolites with Special Emphasis on Tunnelling. Bulletin of Engineering Geology and the Environment, 65, 129-142. https://doi.org/10.1007/s10064-005-0018-x

[7] Ozsoy, E.A., Yilmaz, G. and Arman, H. (2010) Physical, Mechanical and Mineralogical Properties of Ophiolitic Rocks at the Yakakayi Dam Site, Eskisehir, Turkey. Scientific Research and Essays, 5, 2579-2587.

[8] Diamantis, K., Gartzos, E. and Migiros, G. (2014) Influence of Petrographic Characteristics on Physico-Mechanical Properties of Ultrabasic Rocks from Central Greece. Bulletin of Engineering Geology and the Environment, 73, 1273-1292. https://doi.org/10.1007/s10064-014-0584-x

[9] Marinos, G. (1974) Geology of Orthrys and Issues on Its Ophiolites. Ann Geol d Pays Jieneiiiciue.st26, University of Athens, Athens, 118-148.

[10] Mountrakis, D., Sapountzis, E., Kilias, A., Eleftheriadis, G. and Christofides, G. (1983) Paleogeographic Conditions in the Western Pelagonian Margin in Greece during the Initial Rifting of the Continental Area. Canadian Journal of Earth Sciences, 20, 1673-1681. https://doi.org/10.1139/e83-158

[11] Katsikatsos, G., Migiros, G., Triantaphyllis, M. and Mettos, A. (1986) Geological Structure of Internal Hellenides (E. Thessaly-SW Macedonia. Euboea-Attica-Northern Cyclades Islands and Lesvos). IGME, Geol. and Geoph. Res., Special Issue, 191-212.

[12] Migiros, G. (1990) The Lithostratigraphic-Tectonic Structure of Othris (Central Greece). Bulletin of the Geological Society of Greece, 26, 107-120.

[13] ASTM (2001) Standard Practices for Preparing Rock Core Specimens and Determining Dimensional and shape Tolerances. American Society for Testing and Materials, D4543.

[14] Hoek, E. and Brown, E.T. (1980) Underground Excavations in Rock. Inst. Min. 537 Metall, London.

[15] Hawkins, A.B. (1998) Aspects of Rock Strength. Bulletin of Engineering Geology and the Environment, 57, 17-30. https://doi.org/10.1007/s100640050017

[16] ISRM (2007) The Complete ISRM Suggested Methods for Rock Characterization, Testing and Monitoring: 1974-2006. Suggested Methods Prepared by the Commission on Testing Methods, International Society for Rock Mechanics, Compilation Arranged by the ISRM Turkish National Group Ankara, Turkey, 628 p.

[17] ASTM (1983) Test Methods for Ultra Violet Velocities Determination. American Society for Testing and Materials, D2845.

[18] ASTM (2005) Standard Test Method for the Determination of the Point Load Strength Index of Rock. American Society for Testing and Materials, D5731.

[19] ISRM (1981) Rock Characterization Testing and Monitoring. Brown, E., Ed., Pergamon Press, Oxford, $211 \mathrm{p}$.

[20] Foucault, A. and Rault, J.F. (1995) Dictionnaire de geologie. Masson, Paris.

[21] Hoek, E. and Brown, E.T. (1988) The Hoek-Brown Failure Criterion a 1988 Update. Proceedings of the 15th Canadian Rock Mechanics Symposium, Toronto, 3-4 October 1988, 31-38.

[22] Hoek, E., Wood, D. and Shah, S. (1992) A Modified Hoek-Brown Criterion for Jointed Rock Masses. Rock Characterization: ISRM Symposium, Chester, 14-17 September 1992, 209-213. 
[23] Hoek, E., Kaiser, P.K. and Bawden, W.F. (1995) Support of Underground Excavations in Hard Rock. AA Balkema, Rotterdam.

[24] Hoek, E., Carranza-Torres, C.T. and Corkum, B. (2002) Hoek-Brown Failure Criterion2002 Edition. Proceedings of the 5 th North American Rock Mechanics Symposium, Toronto, 7-10 July 2002, 267-273.

Submit or recommend next manuscript to OALib Journal and we will provide best service for you:

- Publication frequency: Monthly

- 9 subject areas of science, technology and medicine

- Fair and rigorous peer-review system

- Fast publication process

- Article promotion in various social networking sites (LinkedIn, Facebook, Twitter, etc.)

- Maximum dissemination of your research work

Submit Your Paper Online: Click Here to Submit

Or Contact service@oalib.com 